\title{
The use of actigraphy in the monitoring of sleep and activity in ADHD: A meta-analysis
}

\author{
Franco De Crescenzo ${ }^{\text {a, b, * }}$, Serena Licchelli ${ }^{b}$, Marco Ciabattini ${ }^{c}$, Deny Menghini ${ }^{b}$, \\ Marco Armando ${ }^{\mathrm{b}}$, Paolo Alfieri ${ }^{\mathrm{b}}$, Luigi Mazzone ${ }^{\mathrm{b}}$, Giuseppe Pontrelli ${ }^{\mathrm{a}}$, \\ Susanna Livadiotti ${ }^{\mathrm{a}}$, Francesca Foti ${ }^{\mathrm{d}, \mathrm{e}}$, Digby Quested ${ }^{\mathrm{f}}$, Stefano Vicari ${ }^{\mathrm{b}}$ \\ a Clinical Trial Unit, University Department of Pediatrics, Bambino Gesù Children's Hospital, IRCCS, Piazza Sant'Onofrio 4, 00100, Rome, Italy \\ b Department of Neuroscience, Bambino Gesù Children's Hospital, IRCCS, Piazza Sant'Onofrio 4, 00100, Rome, Italy \\ ' University of Rome 'Tor Vergata', Via della Ricerca Scientifica snc, 00133, Rome, Italy \\ d Department of Psychology, 'Sapienza' University of Rome, Via dei Marsi 78, 00185, Rome, Italy \\ e IRCCS Fondazione Santa Lucia, Via del Fosso di Fiorano 64, 00143, Rome, Italy \\ ${ }^{\mathrm{f}}$ University of Oxford, Department of Psychiatry, Warneford Hospital, Headington, Oxford, OX3 7JX, United Kingdom
}

\section{A R T I C L E I N F O}

\section{Article history:}

Received 17 August 2014

Received in revised form 15 April 2015

Accepted 15 April 2015

Available online 23 April 2015

\section{Keywords:}

Actigraphy

Attention-deficit disorder with

hyperactivity

Sleep

Children

Meta-analysis

\begin{abstract}
S U M M A R Y
Attention deficit/hyperactivity disorder (ADHD) is the most common neurobehavioral disorder of childhood. There is an increasing need to find objective measures and markers of the disorder in order to assess the efficacy of the therapies and to improve follow-up strategies. Actigraphy is an objective method for recording motor activity and sleep parameters that has been used in many studies in ADHD.

Our meta-analysis aimed to assess the current evidence on the role of actigraphy in both the detection of changes in motor activity and in sleep patterns in ADHD.

A systematic review was carried out to find studies comparing children with unmedicated ADHD versus controls, using actigraphic measures as an outcome. The primary outcome measures were "sleep duration" and daytime "activity mean". As secondary outcome measures we analyzed "sleep onset latency", "sleep efficiency" and "wake after sleep onset".

Twenty-four studies comprising 2179 children were included in this review. We show evidence that ADHD compared to typically developing children present a higher mean activity during structured sessions, a similar sleep duration, and a moderately altered sleep pattern.

This study highlights the role of actigraphy as an objective tool for the ambulatory monitoring of sleep and activity in ADHD.
\end{abstract}

(c) 2015 Elsevier Ltd. All rights reserved.

\section{Introduction}

Attention deficit and hyperactivity disorder (ADHD) is among the most prevalent childhood psychiatric disorders, with an estimated prevalence rate of $5 \%$ [1]. The scientific community agrees that ADHD is a complex and multifactorial disorder and that it is not the result of one clear or single cause. The most frequently cited aetiological hypotheses are genetic, neurochemical, neurobiological, and environmental [2].

\footnotetext{
* Corresponding author. Clinical Trial Unit, Children Hospital Bambino Gesù, Piazza, Sant'Onofrio 4, I-00165, Rome, Italy. Tel.: +3906 68592030; fax: +39 06 68592450.

E-mail address: decrescenzo.franco@gmail.com (F. De Crescenzo).
}

According to the diagnostic and statistical manual of mental disorders, fifth edition (DSM-5) [3], ADHD is characterized by a persistent pattern of inattention and/or hyperactivity-impulsivity that interferes with functioning or development with onset before the age of $12 \mathrm{y}$. More specifically, the DSM-5 diagnosis of ADHD requires six symptoms of hyperactivity and impulsivity or six symptoms of inattention, while for older adolescents and adults (age 17 and older), at least five symptoms are required. Manifestations of ADHD must be present in more than one setting (e.g., home and school, work) and persist for at least six months [3]. The DSM-5 defines three ADHD clinical presentations based on symptom count: combined presentation, predominantly inattentive presentation and predominantly hyperactive/ impulsive presentation. The ICD-10 [4] uses the specific diagnostic term of hyperkinetic disorder (HKD) to describe the 


\begin{tabular}{|c|c|c|c|}
\hline \multirow{2}{*}{\multicolumn{2}{|c|}{ Glossary of terms }} & \multicolumn{2}{|c|}{ K-SADS-PL kiddie-sads-present and lifetime version } \\
\hline & & MFFT & matching familiar figure test \\
\hline \multicolumn{2}{|c|}{ ADDES-Hattention-deficit disorders evaluation scale - home } & MPH & methylphenidate \\
\hline & version & MSLT & multiple sleep latency test \\
\hline \multicolumn{2}{|c|}{$\begin{array}{l}\text { ADDES-S attention-deficit disorders evaluation scale - school } \\
\text { version }\end{array}$} & $\begin{array}{l}\text { NEPSY } \\
\text { NES }\end{array}$ & $\begin{array}{l}\text { developmental neuropsychological assessment } \\
\text { neurobehavioral evaluation }\end{array}$ \\
\hline ADHD & attention-deficit/hyperactivity-disorder & N.R. & not reported \\
\hline ADHDRS & S attention-deficit/hyperactivity-disorder rating scale & PACS & parental account of childhood symptoms \\
\hline APA & American psychiatric association & PIAT & Peabody individual achievement test-revised \\
\hline CBCL & child behavior checklist & PICS & parent interview for child symptoms \\
\hline $\mathrm{CI}$ & confidence interval & PPVT-R & Peabody picture vocabulary test revised \\
\hline CGI-S & clinical global impression - severity of illness & PSG & polysomnography \\
\hline CPRS & Conner's parent rating scale & P-YRMS & parent version of the young mania rating scale \\
\hline CPT & continuous performance test & RCPM & Raven's colored progressive matrices \\
\hline CSHQ & children's sleep habits questionnaire & SLAQ & sleep lab adaptation questionnaire \\
\hline & child symptom inventory-parent and teacher & QUADAS & quality assessment of diagnostic accuracy studies \\
\hline CSP-Q & child sleep questionnaire - parent version & SMD & standardized mean differences \\
\hline CTQ & Conner's teacher questionnaire & SD & standard deviation \\
\hline CTRS & Conner's teacher rating scale & SSD & stop signal delays \\
\hline DISC IV & diagnostic interview schedule for children & SWAN-F & symptoms and normal behavior questionnaire \\
\hline \multirow[t]{2}{*}{ DSM-5 } & diagnostic and statistical manual of mental disorders & TBI & traumatic brain injury \\
\hline & 5th edition & TD & typically developing \\
\hline ESS & Epworth sleepiness scale & TRF & teacher report form \\
\hline \multicolumn{2}{|c|}{$\begin{array}{l}\text { FBB-HKS questionnaire for teacher - hyperkinetic syndrome } \\
\text { HKD }\end{array}$} & TTI & teacher telephone interview \\
\hline HKD & hyperkinetic disorder & WAIS-III & Weschler adult intelligence scale 3rd edition \\
\hline ICD-10 & international classification of diseases 10th Edition & WHO & world health organization \\
\hline ISI-C & insomnia severity index for children & WISC-III & Weschler intelligence scale for children third edition \\
\hline K-ARS & ADHD rating scale, korean edition & WISC IV & Weschler intelligence scale for children fourth edition \\
\hline K-DIPS & diagnostisches interview fur psychische storungen im & WPPSI & Weschler primary and preschool intelligence test \\
\hline & kindesalter & WRAT-R & wide range achievement test revised \\
\hline
\end{tabular}

syndrome, which comes close to meeting the criteria for the combined clinical presentation of DSM-5. Specifically, HKD requires symptoms of impaired attention, hyperactivity and impulsivity in more than one setting (e.g., academic, social, and occupational).

The current clinical understanding of ADHD does not require performance of any screen or test [5] and the assessment includes both a medical and a psychological clinical evaluation based on DSM-5 [3] or ICD-10 [4] criteria. The clinical evaluation of ADHD is multidimensional to capture its situational variability, its associated features, and its impact on home, school, and social functioning. The multi-method assessment approach should include: general medical history; DSM-5 or ICD-10 based parent and child interviews (e.g., Kiddie schedule for affective disorders and schizophrenia for school-age children-present and lifetime, K-SADS-PL [6]); parent- and teacher-completed child behavior rating scales (e.g., Conners third edition [7]); individually administered neuropsychological and intelligence testing (e.g., Wechsler intelligence scale for children -fourth edition [8]); educational achievement testing and screening for learning disabilities; assessment for coexisting psychiatric disorders including oppositional defiant disorder, conduct disorder, mood disorder, anxiety disorder, obsessive compulsive disorder, abuse; general assessment for coexisting medical conditions; educational and psychosocial evaluation. Other assessments might be warranted for further evaluations including: blood lead level, thyroid hormones, genetics consultation/testing, neurology consultation/electroencephalography $[9,10]$. At present, the diagnosis is based on subjective measures and there is an increasing need to find objective measures and markers that overcome the existing differences in definitions and that help to monitor the clinical evolution of individuals with ADHD.

Treatment of ADHD may involve behavioral interventions, school-based interventions, psychological interventions or medication (psychostimulants) alone or in combination. Psychostimulants, such as methylphenidate (MPH), amphetamines and/or various amphetamine and dextro-amphetamine preparations are the most common types of medication that have been shown to be effective for treating ADHD. The treatment strategies for children with ADHD vary according to age [9]. Behavioral interventions include modifications in the physical and social environment that are designed to change behavior using rewards, positive reinforcement, and non-punitive consequences $[9,11]$. Behavioral interventions are preferred to medication as the initial intervention for preschool children with ADHD but medications may be used as an adjunct to behavioral interventions for preschool children (four through five y) who fail to respond to behavioral interventions alone. Combination therapy uses both behavioral/psychological interventions and medication. In a systematic review and a meta-analysis, combination therapy was more effective than behavior/psychological therapy alone in improving core symptoms of ADHD but no more effective than medication treatment alone [12,13]. Parenting programs give parents simple and practical strategies to help them manage their children's behavior, and prevent problems. Schoolbased interventions may include the provision of tutoring or resource room support, classroom modifications, accommodations, or behavioral interventions [9]. 
If left untreated, ADHD is associated with long-term educational and social disadvantage [14]. Indeed, children affected by ADHD are at greater risk for comorbid antisocial behavior, poor academic or vocational performance, substance misuse, and other psychiatric disorders such as anxiety and depression [15]. Moreover in ADHD there is a higher incidence of sleep onset insomnia [10], night awakenings, delayed sleep phase and increased nocturnal activity $[16,17]$ and ADHD symptoms often overlap with those observed in children suffering from sleep deprivation [18]. However, studies examining the association between ADHD or its symptoms and sleep disturbances have yielded inconsistent results [19]. Using subjective (e.g., questionnaires) and objective (neurophysiological) measures, several studies have attempted to clarify the links between ADHD and sleep disorders. Studies using subjective measures (e.g., sleep questionnaires completed by parents) found that children with ADHD have more sleep disturbances compared with typically developing (TD) children, while studies using objective measures (e.g., polysomnography [PSG] and actigraphy) lead to inconsistent results [20]. The heterogeneity of results might be due to the use of medication and the night-to-night variability of sleep [21].

Actigraphy is a non-invasive objective method for recording motor activity and sleep parameters by means of an electronic device worn on the body. The main motor activity parameter assessed by actigraphy is the "activity mean". Sleep parameters are derived from night-time activity scores. The main sleep parameters are "sleep duration", which is the sleep time excluding all periods of wakefulness; "sleep onset latency", which is the time in minutes from getting into bed to actigraphically defined sleep onset (this usually happens after the first $10 \mathrm{~min}$ interval of activity below the threshold set for determining wakefulness); "sleep efficiency", which is the ratio of total sleep time, to nocturnal time in bed; "wake after sleep onset", which is the period of wakefulness after sleep onset. The actigraph allows a patient's activity information to be obtained either in an experimental setting or in a natural setting for a prolonged and continuous period. In recent years, actigraphy has become a major assessment tool, especially in sleep research, sleep medicine, and proved to be reliable [22], valid [23], and cost-effective [24]. In a previous meta-analysis of randomized clinical trials we already evaluated the use of actigraphy as a measure of monitoring activity mean and sleep patterns in children with ADHD treated by MPH [25]. Our results suggested that actigraphy might be a valuable tool for prescribing clinicians who must balance the efficacious effects on hyperactivity against the adverse effects on sleep that MPH may have. However, we recognized that these initial results needed a measure of comparison, since the data comparing actigraphic measures in ADHD versus healthy controls had never been pooled. This implied that we did not have a reliable estimate of the difference between a child with ADHD and a TD child.

The present study therefore is aimed at systematically reviewing and quantitatively synthesizing the current evidence on the role of actigraphy in the detection of changes in activity and sleep patterns in ADHD compared with TD children. Our hypothesis is that actigraphy is a valid measure of the mean activity level and a tool for monitoring its impact on sleep patterns, which could contribute to the clinical diagnosis of ADHD.

\section{Methods}

\section{Literature search}

A literature search of the PubMed/MEDLINE, CINAHL, ISI web of knowledge, Cochrane library, Psychology and behavioral sciences collection databases was carried out to find relevant peer reviewed articles comparing actigraphic measures in children with ADHD versus TD children. A search algorithm based on a combination of the terms: (ADHD OR attention deficit OR 'hyperactivity disorder') AND (actigrap* OR actimet* OR actograp* OR actomet* OR accelerometer) was used. No lower date limit was used and the search was continued until July 2014. To expand our search, reference lists of the retrieved articles were also screened for additional studies (the search strategy is available in the supplementary material as document S1).

\section{Study selection}

All studies or subsets of studies in children with ADHD having an actigraphic assessment for both sleep and activity were eligible for inclusion.

The exclusion criteria were: a) articles not within the field of interest of this review; b) review articles, editorials or letters, comments, conference proceedings; c) case reports; d) studies dated before 1990 if the system used for the diagnosis did not use operationalized criteria, but only disease names with no diagnostic criteria (i.e., ICD-9); e) studies with patients aged more than $18 \mathrm{y}$; f) studies in children with ADHD on a pharmacological treatment; g) studies without a control group of TD children; h) studies without a proper diagnosis of ADHD; i) studies on children with ADHD and a serious concomitant medical illness.

Two researchers (SL and MC) independently reviewed the titles and the abstracts of the retrieved articles, applying the inclusion and exclusion criteria mentioned above. The same two researchers then independently reviewed the full-text version of the articles to confirm their eligibility for inclusion. Disagreements were resolved in a consensus meeting or by a third reviewer (FDC). Considerable care was taken to exclude duplicate publications.

\section{Data extraction}

For each included study, information was collected systematically and independently by the two researchers mentioned above about the publication (author names, journal, year of publication, country of origin), the patient and the comparison characteristics (gender, age, how the diagnosis was made, the outcomes of the study, actigraphic methodological features). Data were then extracted independently and entered into RevMan 5.3 software by two review authors (MC, FDC).

\section{Outcome measures}

The primary outcome measures were the analyses of "sleep duration" and of "activity mean". As secondary outcomes, we analysed "sleep latency", "sleep efficiency" and "wake after sleep onset", which are considered less reliable parameters for actigraphy $[22]$.

\section{Quality assessment}

The methodological quality and potential sources of bias for each study were assessed by using the quality assessment of diagnostic accuracy studies (QUADAS) [26]. This instrument consists of eleven items. The first of them assesses the representative spectrum; the second, fourth, fifth and sixth item examine the applicability of an appropriate reference standard; the third item assesses the presence of a delay between the tests; the seventh and eighth items assess the blinding; the ninth indicates whether relevant clinical information was available 
during the interpretation of results; the tenth item examines whether all the results were reported; while the eleventh item assesses whether all the withdrawals from the study were explained. Two authors scored independently (SL, MC), and differences were resolved by consensus or by a third reviewer (FDC). Moreover, funnel plots were visually checked to exclude the presence of publication bias.

\section{Data analysis}

Consistent with meta-analytic recommendations [27], we synthesized and analysed our set of studies. This procedure involved the following steps: a) calculating standardized mean difference (SMD) effect sizes for each comparison with confidence intervals (95\%); b) determining an overall effect size; c) estimating heterogeneity.

Data for each study were expressed as standardized mean difference, since differences on actigraphic devices and on storage rates used suggested we should think of them as different measurement scales, using the random effects model which is more conservative than the fixed-effects model. To check for the existence of publication bias, visual inspection of the data was completed using funnel plots, and any potential outliers were identified within each domain. Qualitative data have been presented descriptively.

The $\mathrm{I}^{2}$ index was used to assess the heterogeneity of effect sizes [28]. Its value lies between 0 and 100 and estimates the percentage of variation among effect sizes that can be attributed to heterogeneity. A significant $\mathrm{I}^{2}$ suggests that the effect sizes analysed are not estimating the effect size of the same population. Following Higgins et al. [28], we discussed $\mathrm{I}^{2}$ thresholds of $25 \%, 50 \%$ and $75 \%$ to differentiate low, moderate and high heterogeneity. In interpreting SMD values, we considered SMD "small" if $<0.40$, "moderate" from 0.40 to 0.70 and "large" if $>0.7$ [27]. In order to address heterogeneity, to estimate outliers and to examine the robustness of the results, we performed a sensitivity analysis using the jackknife method for the primary outcomes [29].

Moreover, we decided to perform a separate sensitivity analysis on the activity mean during the $24 \mathrm{~h}$ and during structured experimental sessions.

\section{Results}

\section{Selected studies}

The literature search generated 354 articles. Reviewing titles and abstracts, articles were excluded applying the criteria mentioned above: 268 studies were excluded because they were not within the field of interest of this review and 86 articles were retrieved in full text. Of these, 25 studies were excluded because some of the participants or all of them were on pharmacological treatment; 16 studies were excluded due to lack of TD control population or no control population at all; three were letters to the editor; 12 were studies with a population without a proper ADHD diagnosis; four studies were with subjects older than $18 \mathrm{y}$; one study was with children with developmental coordination disorder and comorbid ADHD and one study was not on humans (references of the excluded studies are available in the supplementary material as document S2).

Finally, 24 studies comprising 2179 participants were included in a qualitative synthesis [17,19,30-51]. Of these 19 studies (eight assessing activity mean and eleven studies assessing sleep parameters) comprising a total of 1323 children (631 ADHD and 692 TD) were included in the quantitative analysis (see flow chart as Fig. 1).

\section{Study characteristics}

The characteristics of the included studies are presented in Table 1. Almost all the studies retrieved were in English, but one was in German [47]. The majority of participants were male, with a mean age of nine years, one study included children between three and four years [30] and one study included adolescents with a mean age of $15.1 \mathrm{y}$ for ADHD and $14.1 \mathrm{y}$ for controls [38].

The methodological aspects of actigraphic devices are presented in Table 2. Actigraphic devices varied and the specific types of device were not always reported. Actigraphic devices were worn in most studies on the non-dominant wrist, but some reported their use on the ankles or on the waist. The storage rate used was not always reported, but for the most, it was around $1 \mathrm{~min}$ epoch. When the actigraph was used to detect activity mean, the device was continuously used during $24 \mathrm{~h}$ only in two studies [39,42], while for the rest of the studies it was on average used only for a couple of hours during experimental sessions.

\section{Primary outcomes}

Effect sizes with 95\% confidence intervals for each parameter from each individual study plus the pooled results from the meta-analyses are shown in Tables 3-7. The primary outcomes are shown in Tables 3 and 4 . The meta-analysis indicates that children with ADHD have a moderately increased activity mean compared to TD (SMD $=0.65[0.45,0.84], \mathrm{P}<0.00001)$. There is homogeneity among the studies $\left(\mathrm{I}^{2}=19 \%\right)$ and the jackknife analysis (see Table S3) confirms the robustness of this result. The sensitivity analysis dividing the results of the activity mean during the $24 \mathrm{~h}$ and during structured experimental sessions highlights that only two small studies reported an activity mean during the $24 \mathrm{~h}[39,42]$ and the pooled meta-analysis does not show a statistical difference between ADHD and TD children. However reaching statistically significant results would have been difficult due to the size of the studies (28 ADHD compared to 28 TD children), which resulted in a wide confidence interval $(\mathrm{SMD}=0.24[-0.29,0.77])$. We found instead that results are highly suggestive towards the use of actigraphy during structured experimental sessions, with a strong increase of activity mean and a clear homogeneity among the studies (SMD $=0.71$ $\left.[0.51,0.90]) ; \mathrm{I}^{2}=15 \%\right)$.

Notably, we had to exclude Rapport et al. (2009) [41] from the analyses, since it presented results as a sum of three actigraphic devices. Its results highlight a much higher activity mean in ADHD compared with TD children (SMD = 2.43 [1.31, 3.56]).

The meta-analysis of sleep duration is not significant and indicates that there is no evidence that children with ADHD compared to TD have different sleep duration. There is homogeneity among the studies $\left(\mathrm{I}^{2}=7 \%\right)$, while the jackknife analysis (see Table S4) suggests a possible small reduction in sleep duration for ADHD children.

\section{Secondary outcomes}

The secondary outcomes are shown in Tables 5-7 The metaanalysis of sleep latency shows a significant and moderate increase in ADHD compared to TD children (SMD $=0.51$ [0.10, 0.92]). The high heterogeneity $\left(\mathrm{I}^{2}=79 \%\right)$ creates a larger confidence interval in the random effects model, but the estimate remains significant $(P=0.01)$. The sleep efficiency parameter also indicates a moderate effect with a lower score in ADHD (SMD $=-0.69$ $[-1.32,-0.05])$. Notwithstanding the high heterogeneity $\left(\mathrm{I}^{2}=89 \%\right)$, the results remain statistically significant $(P=0.03)$. On the other hand there is no evidence of a statistically significant difference in 


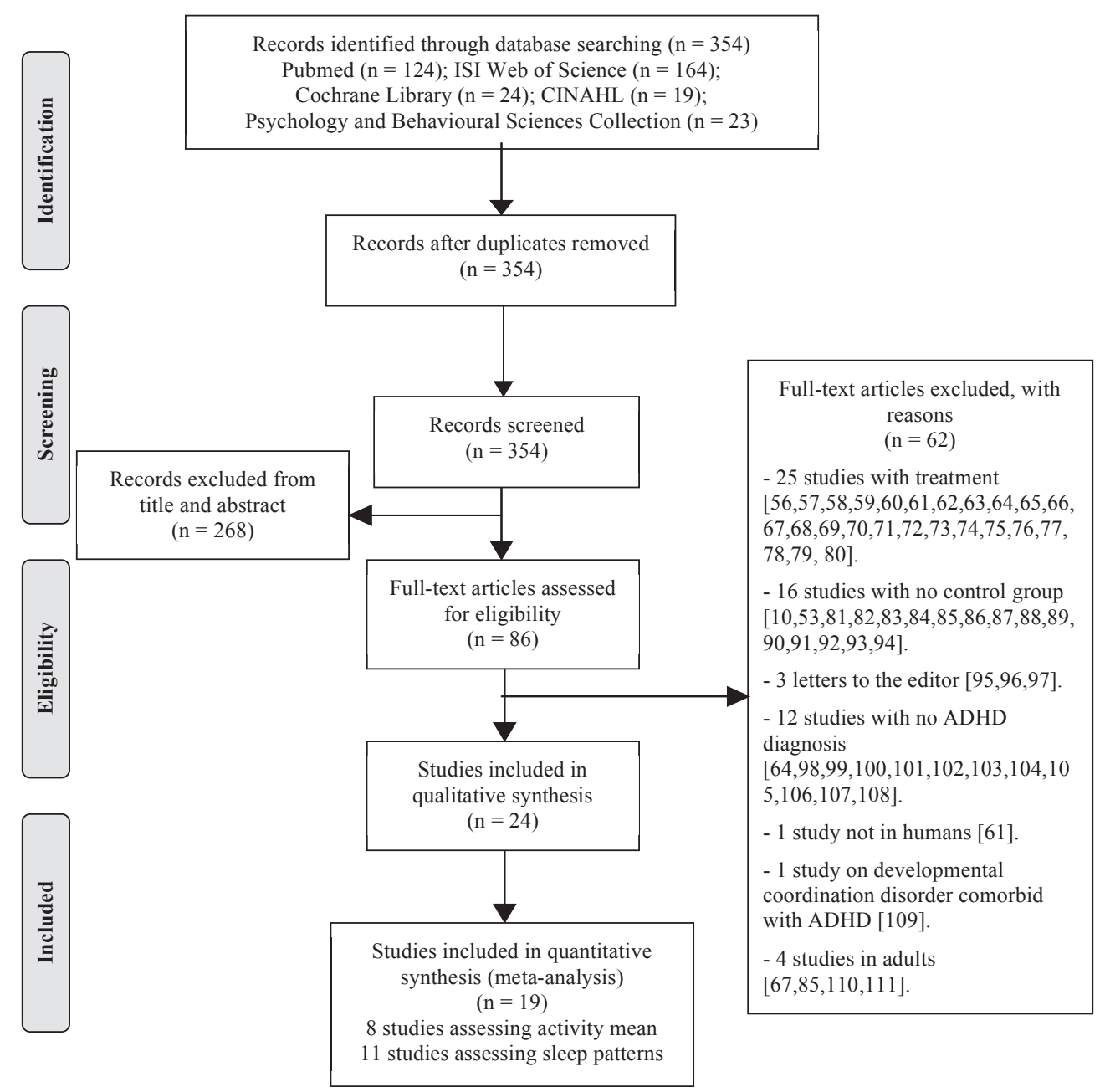

Fig. 1. Flow chart. References of the excluded studies are available in the supplementary material as document S2.

wakefulness between ADHD and TD children judging from the wake after sleep onset data (SMD $\left.=0.06[-0.16,0.28] ; \mathrm{I}^{2}=45 \%\right)$.

\section{Quality assessment}

Assessment of the methodological quality of included articles according to the QUADAS criteria is reported in Table 8. Three of the criteria were met by all studies. None of the studies had representative spectrum and reference standard results and index test results were not blinded. Withdrawals were considered insufficiently explained only in one study [41]. The reference standard was not considered acceptable if in the original article it was not accurately reported that all the participants had a visit to an appropriate mental health professional. Visual inspection of the funnel plots was not suggestive of publication bias.

\section{Post-hoc analysis}

Since ADHD prevalence was found to be higher in males in various clinical studies with a ratio as high as 10 to 1 [52,53], we decided to perform a subgroup analysis to differentiate studies with $100 \%$ males for both patients with ADHD and healthy controls from studies with males and females and to analyze if gender had any impact on the activity mean. For the studies investigating the activity mean, only Tsujii et al. [42] and Alderson et al. [34] had 100\% males for both patients with ADHD and healthy controls. The pooled population of males comprised 29 patients with ADHD versus 29 healthy controls (SMD $=0.79[-0.51,2.09]$ ). The pooled population of studies with males and females, without Tsujii et al. [42] and Alderson et al. [34], for the activity mean comprised 305 patients with ADHD versus 237 healthy controls (SMD $=0.67$ [0.49, $0.84]$ ). This subgroup analysis shows that there is no significant difference in activity mean between patients with ADHD and healthy controls, if we take only studies in males. However, the large confidence interval and the small population included do not allow more in depth considerations. Therefore, at this stage we cannot exclude a gender effect and more research is needed to investigate this issue.

\section{Discussion}

The results show evidence for a higher activity mean in ADHD compared to TD children, as expected, while there is no evidence for altered sleep duration. The secondary outcomes show that sleep latency and sleep efficiency appear altered in ADHD while wakefulness periods are not significantly different compared to TD children.

The results of the meta-analysis of activity mean are clear and robust. The low heterogeneity and the jackknife analysis support a finding of higher motor activity in ADHD. The clinical usefulness of this finding is demonstrated in other studies through the positive correlation of the activity mean with poorer levels of performance 
Table 1

Included studies.

\begin{tabular}{|c|c|c|c|c|c|}
\hline Study & Participants & $\begin{array}{l}\text { Gender } \\
\text { (\%males) }\end{array}$ & Age, y (SD) & Diagnostic assessment & Outcomes \\
\hline Miyahara M et al. 2014 & $\begin{array}{l}93 \text { ADHD } \\
76 \text { Controls }\end{array}$ & $71 \%$ & $\begin{array}{l}\text { ADHD: } 3.73 \\
\text { Controls: } 3.69\end{array}$ & $\begin{array}{l}\text { ADHDRS } \\
\text { WPPSI } \\
\text { Mental health professionals } \\
\text { (pediatricians, neurologists, } \\
\text { school psychologists) }\end{array}$ & $\begin{array}{l}\text { Actigraphy } \\
\text { NEPSY }\end{array}$ \\
\hline Moreau V et al. 2014 & $\begin{array}{l}41 \text { ADHD } \\
41 \text { Controls }\end{array}$ & $58.5 \%$ & $\begin{array}{l}\text { ADHD: } 9.74(1.68) \\
\text { Controls: } 9.56(1.62)\end{array}$ & $\begin{array}{l}\mathrm{CBCL} \\
\text { CPRS } \\
\text { K-SADS-PL }\end{array}$ & $\begin{array}{l}\text { Actigraphy } \\
\text { CBCL } \\
\text { CSHQ } \\
\text { ISI-C } \\
\text { Sleep diary }\end{array}$ \\
\hline Bessey $M$ et al. 2013 & $\begin{array}{l}25 \text { ADHD } \\
25 \text { Controls }\end{array}$ & $88 \%$ & $\begin{array}{l}\text { ADHD: } 8.8(1.8) \\
\text { Controls: } 8.8(1.9)\end{array}$ & $\begin{array}{l}\text { CPRS } \\
\text { CTRS }\end{array}$ & $\begin{array}{l}\text { Actigraphy } \\
\text { SLAQ }\end{array}$ \\
\hline Wiebe S et al. 2013 & $\begin{array}{l}20 \text { ADHD } \\
46 \text { Controls }\end{array}$ & $64 \%$ & $\begin{array}{l}\text { ADHD: } 9.2(1.6) \\
\text { Controls: } 8.7(1.1)\end{array}$ & $\begin{array}{l}\text { CBCL } \\
\text { CPRS } \\
\text { DISC IV }\end{array}$ & $\begin{array}{l}\text { Actigraphy } \\
\text { Polysomnography } \\
\text { ESS } \\
\text { MSLT } \\
\text { Sleep log }\end{array}$ \\
\hline Alderson $M$ et al. 2012 & $\begin{array}{l}11 \text { ADHD } \\
11 \text { Controls }\end{array}$ & $100 \%$ & $\begin{array}{l}\text { ADHD: } 8.64(1.29) \\
\text { Controls: } 9.45(1.44)\end{array}$ & $\begin{array}{l}\text { K-SADS- PL } \\
\text { CBCL } \\
\text { TRF } \\
\text { CSI } \\
\text { WISC III-IV }(\mathrm{QI}>85)\end{array}$ & $\begin{array}{l}\text { Actigraphy } \\
\text { SSD } \\
\text { Choice task } \\
\text { Control condition (Microsoft Paint) }\end{array}$ \\
\hline Langevin $R$ et al. 2012 & $\begin{array}{l}5 \text { ADHD + NTP } \\
5 \text { ADHD } \\
5 \text { Controls }\end{array}$ & $80 \%$ & Total: 8.13 & DSM-IV & $\begin{array}{l}\text { Actigraphy } \\
\text { Sleep agenda } \\
\text { SWAN-F }\end{array}$ \\
\hline Gruber $R$ et al. 2011 & $\begin{array}{l}11 \text { ADHD } \\
32 \text { Controls }\end{array}$ & $63 \%$ & $\begin{array}{l}\text { ADHD: } 8.7(1.3) \\
\text { Controls: } 8.8(1.3)\end{array}$ & $\begin{array}{l}\text { DISC-IV } \\
\text { CBCL } \\
\text { CPRS } \\
\text { WISC-IV }(\mathrm{QI}>80)\end{array}$ & $\begin{array}{l}\text { Actigraphy } \\
\text { Polysomnography } \\
\text { ESS } \\
\text { Sleep log } \\
\text { CPT }\end{array}$ \\
\hline Kam HJ et al. 2011 & $\begin{array}{l}10 \text { ADHD } \\
7 \text { Controls }\end{array}$ & $53 \%$ & $\begin{array}{l}\text { ADHD: } 7.2(0.63) \\
\text { Controls: } 7.5(0.53)\end{array}$ & $\begin{array}{l}\text { CBCL } \\
\text { K-ARS } \\
\text { K-SADS-PL }\end{array}$ & Actigraphy \\
\hline Mullin BC et al. 2011 & $\begin{array}{l}13 \mathrm{BD} \\
14 \mathrm{ADHD} \\
21 \text { Controls }\end{array}$ & $58 \%$ & $\begin{array}{l}\text { BD: } 14.4(2.1) \\
\text { ADHD: } 15.1(2.1) \\
\text { Controls: } 14.1(2.0)\end{array}$ & $\begin{array}{l}\text { K-SADS- PL } \\
\text { P- YMRS }\end{array}$ & $\begin{array}{l}\text { Actigraphy } \\
\text { Sleep diary }\end{array}$ \\
\hline Licht $C A$ et al. 2009 & $\begin{array}{l}9 \text { ADHD } \\
9 \text { Controls }\end{array}$ & $83 \%$ & $\begin{array}{l}\text { ADHD: } 9.33(1.00) \\
\text { Controls: } 9.11(1.17)\end{array}$ & $\begin{array}{l}\text { PPVT-R ( }>85 \text { ) } \\
\text { Barkley's ADHD } \\
\text { Clinical parent interview } \\
\text { ADDES-S } \\
\text { ADDES-H }\end{array}$ & Actigraphy \\
\hline Owens J et al. 2009 & $\begin{array}{l}107 \text { ADHD } \\
46 \text { Controls }\end{array}$ & $69 \%$ & $\begin{array}{l}\text { ADHD: } 10.2(2.0) \\
\text { Controls: } 10.3(2.6)\end{array}$ & $\begin{array}{l}\text { ADHDRS } \\
\text { K-SADS PL } \\
\text { CGI S } \\
\text { WISC IV }(Q I>80)\end{array}$ & $\begin{array}{l}\text { Actigraphy } \\
\text { Electronic diaries }\end{array}$ \\
\hline Rapport MD et al. 2009 & $\begin{array}{l}12 \text { ADHD } \\
11 \text { Controls }\end{array}$ & $100 \%$ & Total: 9.04 (1.36) & $\begin{array}{l}\text { K-SDAS PL } \\
\text { CBCL } \\
\text { TRF } \\
\text { CSI } \\
\text { WISC III-IV }\end{array}$ & $\begin{array}{l}\text { Actigraphy } \\
\text { Phonologic working memory task } \\
\text { Visuospatial working memory task } \\
\text { Controls (Microsoft Paint) }\end{array}$ \\
\hline Tsujii $N$ et al. 2009 & $\begin{array}{l}18 \text { ADHD } \\
10 \text { PDD }+ \\
\text { hyperactivity ( } 3 \text { Asperger, } \\
7 \text { unspecified PDD) } \\
18 \text { Controls }\end{array}$ & $100 \%$ & $\begin{array}{l}\text { ADHD: } 9.33(1.41) \\
\text { PDD: } 9.2(1.75) \\
\text { Controls: } 9.17(1.2)\end{array}$ & $\begin{array}{l}\text { Clinical Interview } \\
\text { CBCL } \\
\text { TRF } \\
\text { WISC III }(\mathrm{QI}>70)\end{array}$ & Actigraphy \\
\hline Wood AC et al. 2009 & $\begin{array}{l}116 \text { ADHD (combined } \\
\text { type) } \\
119 \text { Siblings } \\
218 \text { Controls }\end{array}$ & $82 \%$ & $\begin{array}{l}\text { ADHD: } 11.90(2.74) \\
\text { Siblings: } 11.51(2.85) \\
\text { Controls: } 12.76\end{array}$ & $\begin{array}{l}\text { PACS } \\
\text { CPRS } \\
\text { CTRS }\end{array}$ & Actigraphy \\
\hline Halperin JM et al. 2008 & $\begin{array}{l}98 \text { ADHD } \\
85 \text { Controls }\end{array}$ & $100 \%$ & $\begin{array}{l}\text { ADHD: } 18.30(1.60) \\
\text { Controls: } 18.51(1.66)\end{array}$ & K-SADS PL & $\begin{array}{l}\text { Actigraphy } \\
\text { WAIS III } \\
\text { Stroop color-word test } \\
\text { CPT }\end{array}$ \\
\hline Hvolby $A$ et al. 2008 & $\begin{array}{l}45 \text { ADHD } \\
64 \text { other psychiatric } \\
\text { diagnoses } \\
97 \text { Controls }\end{array}$ & $74 \%$ & $\begin{array}{l}\text { ADHD: } 8.4 \\
\text { Psychiatric control group: } 8.6 \\
\text { Controls: } 8\end{array}$ & $\begin{array}{l}\text { K-SADS PL } \\
\text { ADHD- RS }\end{array}$ & $\begin{array}{l}\text { Actigraphy, } \\
\text { Sleep diaries }\end{array}$ \\
\hline Gruber $R$ et al. 2004 & $\begin{array}{l}24 \mathrm{ADHD} \\
25 \text { Controls }\end{array}$ & $100 \%$ & $\begin{array}{l}\text { ADHD: } 8.94(1.25) \\
\text { Controls: } 8.83(1.01)\end{array}$ & K-SADS PL & $\begin{array}{l}\text { Actigraphy } \\
\text { Sleep Habits Questionnaire } \\
\text { NES }\end{array}$ \\
\hline Salbach $H$ et al. 2002 & $\begin{array}{l}31 \text { ADHD } \\
31 \text { Controls }\end{array}$ & - & $\begin{array}{l}\text { ADHD: } 9.1 \\
\text { Controls: } 9.6\end{array}$ & $\begin{array}{l}\text { ICD } 10 \\
\text { Achenbach teachers } \\
\text { questionnaire } \\
\text { CTRS } \\
\text { DIPS }\end{array}$ & $\begin{array}{l}\text { Actigraph } \\
\text { Delay Gratification Test (DGT) } \\
\text { Continuous Performance Test (CPT) } \\
\text { TRF } \\
\text { CTRS }\end{array}$ \\
\hline
\end{tabular}


Table 1 (continued)

\begin{tabular}{|c|c|c|c|c|c|}
\hline Study & Participants & $\begin{array}{l}\text { Gender } \\
\text { (\%males) }\end{array}$ & Age, y (SD) & Diagnostic assessment & Outcomes \\
\hline Corkum P et al. 2001 & $\begin{array}{l}25 \text { ADHD } \\
25 \text { Controls }\end{array}$ & $80 \%$ & $\begin{array}{l}\text { ADHD: } 9.12(1.42) \\
\text { Controls: } 9.72(1.31)\end{array}$ & $\begin{array}{l}\text { Parent and teacher interviews } \\
\text { Child assessment }\end{array}$ & $\begin{array}{l}\text { Actigraphy } \\
\text { CSP-Q } \\
\text { Sleep diaries }\end{array}$ \\
\hline Dane $A V$ et al. 2000 & $\begin{array}{l}20 \text { ADHD-I } \\
22 \text { ADHD-C } \\
22 \text { Controls }\end{array}$ & $76.5 \%$ & $\begin{array}{l}\text { ADHD I: } 9.28(1.44) \\
\text { ADHD C: } 9.11(1.47) \\
\text { Controls: } 9.14(1.38)\end{array}$ & $\begin{array}{l}\text { Clinical diagnostic protocol } \\
\text { PICS } \\
\text { TTI } \\
\text { Ontario Child Helath } \\
\text { Study Scale }\end{array}$ & $\begin{array}{l}\text { Actigraphy } \\
\text { IOWA Conner's rating scale }\end{array}$ \\
\hline Gruber $R$ et al. 2000 & $\begin{array}{l}38 \text { ADHD } \\
64 \text { Controls }\end{array}$ & $100 \%$ & $\begin{array}{l}\text { ADHD: } 9.6(2.7) \\
\text { Controls: } 9.4(1.7)\end{array}$ & $\begin{array}{l}\text { ADHD Symptom checklist } \\
\text { CBCL }\end{array}$ & $\begin{array}{l}\text { Actigraphy } \\
\text { Daily sleep logs }\end{array}$ \\
\hline Konrad $K$ et al. 2000 & $\begin{array}{l}31 \text { ADHD } \\
27 \text { TBI } \\
26 \text { Controls }\end{array}$ & $68 \%$ & $\begin{array}{l}\text { ADHD: } 10.5(1.6) \\
\text { TBI: } 10.6(1.7) \\
\text { Controls: } 10.2(1.2)\end{array}$ & $\begin{array}{l}\text { K-DIPS } \\
\text { PICS } \\
\text { FBB-HKS }\end{array}$ & $\begin{array}{l}\text { Stop signal task } \\
\text { Delayed response task } \\
\text { Actigraphy }\end{array}$ \\
\hline Inoue K et al. 1998 & $\begin{array}{l}20 \text { ADHD } \\
52 \text { Controls }\end{array}$ & $100 \%$ & $\begin{array}{l}\text { ADHD: } 9 \\
\text { Controls: } 9.5\end{array}$ & DSM-III-R & $\begin{array}{l}\text { CPT } \\
\text { WISC-R } \\
\text { MFFT } \\
\text { Actigraphy }\end{array}$ \\
\hline Halperin JM et al. 1992 & $\begin{array}{l}31 \text { ADHD } \\
53 \text { Patients No ADHD } \\
18 \text { Controls }\end{array}$ & $81 \%$ & $\begin{array}{l}\text { ADHD: } 9.6(1.83) \\
\text { No ADHD: } 10.1(1.7) \\
\text { Controls: } 9.1(1.8)\end{array}$ & $\begin{array}{l}\text { CBCL } \\
\text { CTQ }\end{array}$ & $\begin{array}{l}\text { Actigraphy } \\
\text { RCPM } \\
\text { PPVT-R } \\
\text { WRAT-R } \\
\text { PIAT-R } \\
\text { CPT }\end{array}$ \\
\hline
\end{tabular}

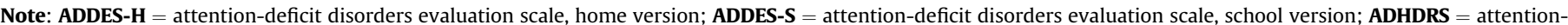

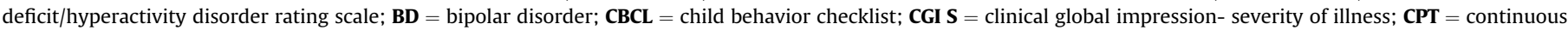

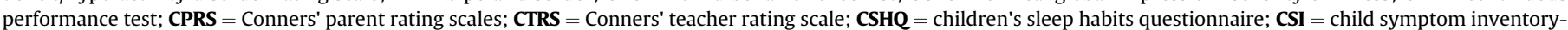

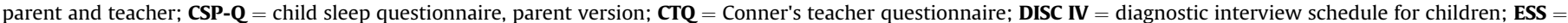

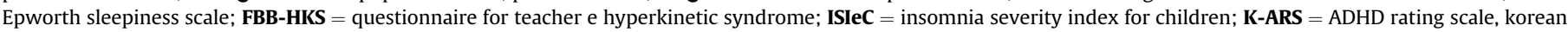

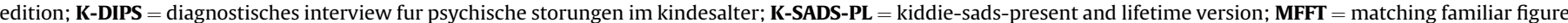

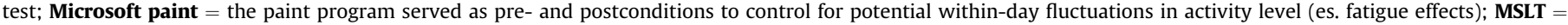

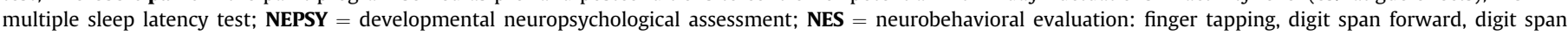

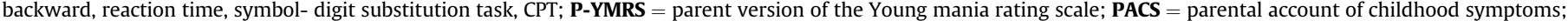

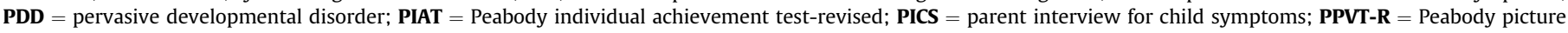

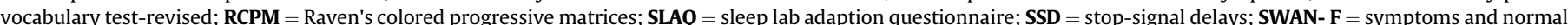

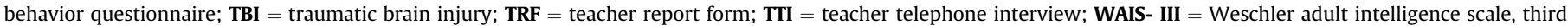

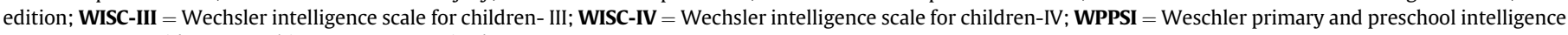
test; $\mathbf{W R A T R}=$ wide range achievement test-revised.

Table 2

Methodological aspects of actigraphic devices in studies included.

\begin{tabular}{|c|c|c|c|c|}
\hline Study & Type of device & Where worn & When recorded & $\begin{array}{l}\text { Storage rate } \\
\text { used }\end{array}$ \\
\hline Miyahara M et al. 2014 & AM7164; Actigraph, Fort Walton Beach, FL & Non dominant ankle, waist & Experimental session & N.R. \\
\hline Moreau $V$ et al. 2014 & AW-64 Mini-Mitter & Wrist & 5 nights & 0.5 min epoch \\
\hline Bessey $M$ et al. 2013 & Basic Mini Motionlogger; Ambulatory Monitoring Inc., NY & Wrist & 6 nights + sleep lab & N.R. \\
\hline Wiebe S et al. 2013 & AW-64 Mini-Mitter & Non dominant wrist & 5 nights & $1 \mathrm{~min}$ epoch \\
\hline Alderson $M$ et al. 2012 & Basic Mini Motionlogger; Ambulatory Monitoring Inc., NY & Non dominant wrist & Experimental session & $1 \mathrm{~min}$ epoch \\
\hline Langevin $R$ et al. 2012 & AW-64 Mini-Mitter & Non dominant wrist & $\begin{array}{l}2 \text { measuring times, } \\
5 \text { weekdays each }\end{array}$ & N.R. \\
\hline Gruber $R$ et al. 2011 & AW-64 Mini-Mitter & N.R. & $24 \mathrm{~h}$ & $1 \mathrm{~min}$ epoch \\
\hline Kam HJ et al. 2011 & LIG NEX1 Co., Ltd., Yangin, Korea & Non dominant wrist & During a school lesson & 1 min epoch \\
\hline Mullin BC et al. 2011 & AW-64 Mini-Mitter & Non dominant wrist & 4 nights & $1 \mathrm{~min}$ epoch \\
\hline Licht CA et al. 2009 & $\begin{array}{l}\text { Computer science and Applications } \\
\text { (CSA)/Manufacturing Technology, Inc. }\end{array}$ & Waist & $14 \mathrm{~d}(8-15) 24 \mathrm{~h}$ a day & 1 min epoch \\
\hline Owens J et al. 2009 & AW-64 Mini-Mitter & Non dominant wrist & 3 visits in $10-24$ nights & $1 \mathrm{~min}$ epoch \\
\hline Rapport MD et al. 2009 & Basic Mini Motionlogger; Ambulatory Monitoring Inc., NY & Non dominant wrist, ankles & Experimental session & $1 \mathrm{~min}$ epoch \\
\hline Tsujii $N$ et al. 2009 & $\begin{array}{l}\text { Mini Motionlogger; Ambulatory } \\
\text { Monitoring Inc., NY }\end{array}$ & Non dominant wrist & $1 \mathrm{wk}$ at school & 1 min epoch \\
\hline Wood AC et al. 2009 & $\begin{array}{l}\text { MTI Health services Version } 323 \\
\text { Health One Technology, Pensacola, FL }\end{array}$ & Dominant leg, waist & $2 \mathrm{~h}$ with a $25 \mathrm{~min}$ break & 1 min epoch \\
\hline Halperin JM et al. 2008 & CSA activity monitor & Non dominant ankle, waist & Experimental session & 1 min epoch \\
\hline Hvolby $A$ et al. 2008 & Mini Motionlogger; Ambulatory Monitoring, Inc, Ardsley, NY & Dominant wrist & 5 nights & N.R. \\
\hline Gruber R et al. 2004 & Mini Motionlogger; Ambulatory Monitoring Inc. Ardsley, NY & Non dominant wrist & 5 nights & $1 \mathrm{~min}$ epoch \\
\hline Salbach $H$ et al. 2002 & N.R. & N.R. & N.R. & N.R. \\
\hline Corkum P et al. 2001 & Mini Motionlogger; Ambulatory Monitoring Inc., NY & Non dominant wrist & 7 nights & $1 \mathrm{~min}$ epoch \\
\hline Dane $A V$ et al. 2000 & Ambulatory Monitoring Inc. 1996 & Non dominant wrist & $\begin{array}{l}2 \mathrm{~h} \text { period and a second } \\
2 \mathrm{~h} \text { interval }\end{array}$ & 1 min epoch \\
\hline Gruber $R$ et al. 2000 & N.R. & N.R. & 5 nights & N.R. \\
\hline Konrad K et al. 2000 & Cambridge Neurotechnology, Version 2.56 & Preferred arm & Experimental session & 0.25 min epoch \\
\hline Inoue $K$ et al. 1998 & N.R. & Waist & Experimental session & 1 min epoch \\
\hline Halperin JM et al. 1992 & N.R. & Waist & Experimental session & N.R. \\
\hline
\end{tabular}

N.R. $=$ not reported. 
Table 3

Activity mean.

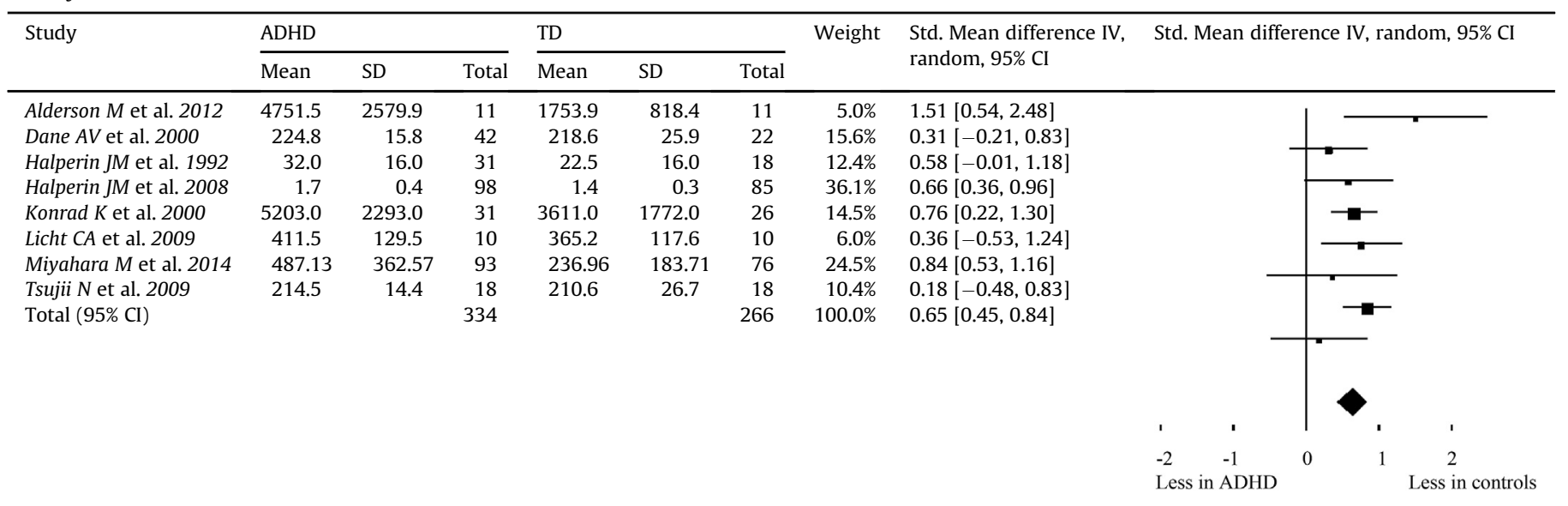

Notes: ADHD = attention deficit/hyperactivity disorder; $\mathrm{CI}=$ confidence interval; $\mathrm{IV}=$ inverse variance method; $\mathrm{SD}=\mathrm{standard}$ deviation; TD = typically developing. Heterogeneity: $\mathrm{Tau}^{2}=0.02 ; \mathrm{Chi}^{2}=8.68, \mathrm{df}=7(\mathrm{P}=0.28) ; \mathrm{I}^{2}=19 \%$.

Test for overall effect: $\mathrm{Z}=6.41(\mathrm{P}<0.00001)$.

and lower levels of functioning [54,55]. The sensitivity analysis shows strong evidence of a large effect during structured experimental sessions. As a whole, these findings suggest that actigraphy might be used by the clinician in the monitoring of activity during structured sessions (e.g., during psychological tests in outpatient setting) and suggest that more research is warranted to understand whether children with ADHD move more than TD children throughout the whole day.

Sleep duration is not significantly different between ADHD and TD children and there is homogeneity between the studies $\left(\mathrm{I}^{2}=7 \%\right)$. However, the jackknife analysis on sleep duration is significant (SMD $=-0.10[-0.15,-0.05])$ and this means that some evidence for lower sleep duration in ADHD might derive from more and larger studies (see Table S4). Nevertheless, we believe that the sample analysed by our meta-analysis (297 ADHD and 426 TD) is sufficiently large and that although important for research purposes, smaller differences in sleep duration are unlikely to be clinically meaningful.

The secondary outcomes indicate an altered pattern of sleep. As we expected, the secondary outcomes present with high heterogeneity and are less reliable than the primary ones. This is because actigraphy is not very sensitive for wakefulness periods [56] and sleep efficiency is intimately correlated to wake after sleep onset. Indeed sleep latency presents with a high heterogeneity, but it is not considered as a very reliable parameter in actigraphy [22]. In order to address heterogeneity we used the random effects model, which is more conservative than the fixed effects model. Notwithstanding this, the significant results tell us that by using actigraphy we might find an altered sleep pattern in ADHD children, even if they do not present with sleep problems and even if

Table 4

Sleep duration.

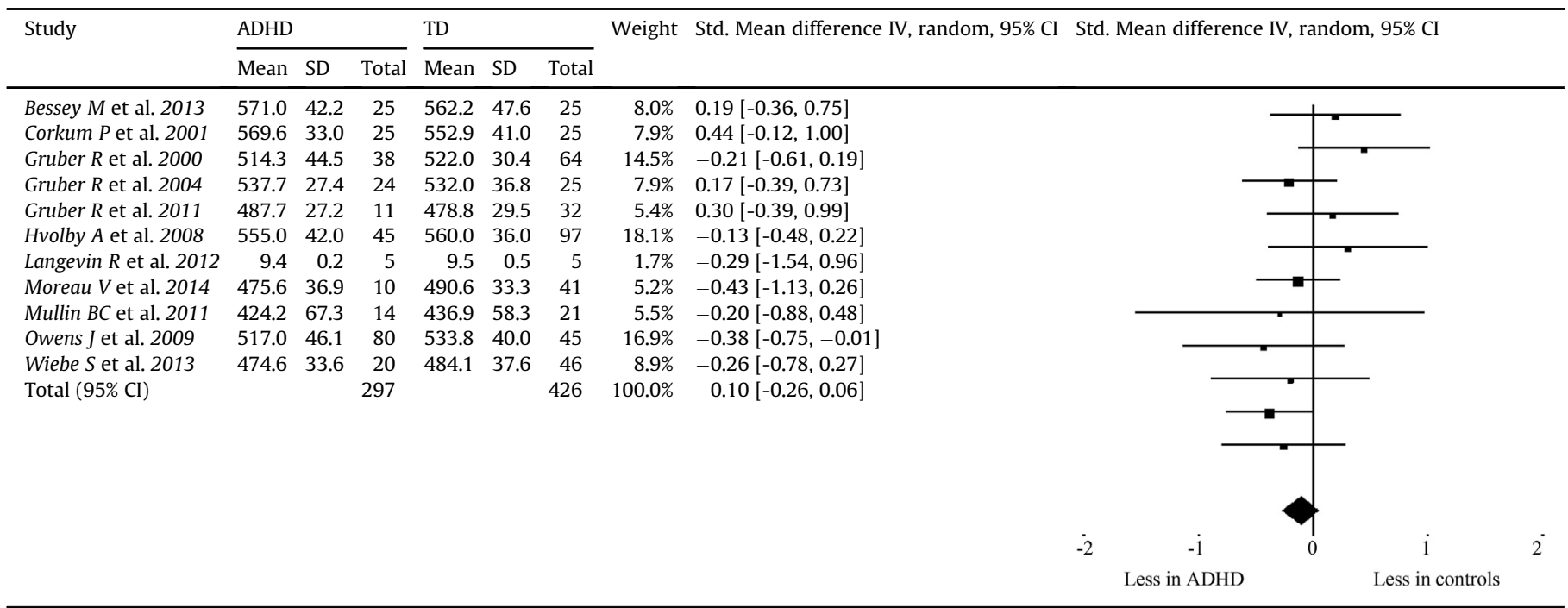

Notes: $\mathrm{ADHD}=$ attention deficit/hyperactivity disorder; $\mathrm{CI}=$ confidence interval; $\mathrm{IV}=$ inverse variance method; $\mathrm{SD}=\mathrm{standard}$ deviation; $\mathrm{TD}=$ typically developing. Heterogeneity: $\mathrm{Tau}^{2}=0.01 ; \mathrm{Chi}^{2}=10.79, \mathrm{df}=10(\mathrm{P}=0.37) ; \mathrm{I}^{2}=7 \%$.

Test for overall effect: $Z=1.20(P=0.23)$. 
Table 5

Sleep latency.

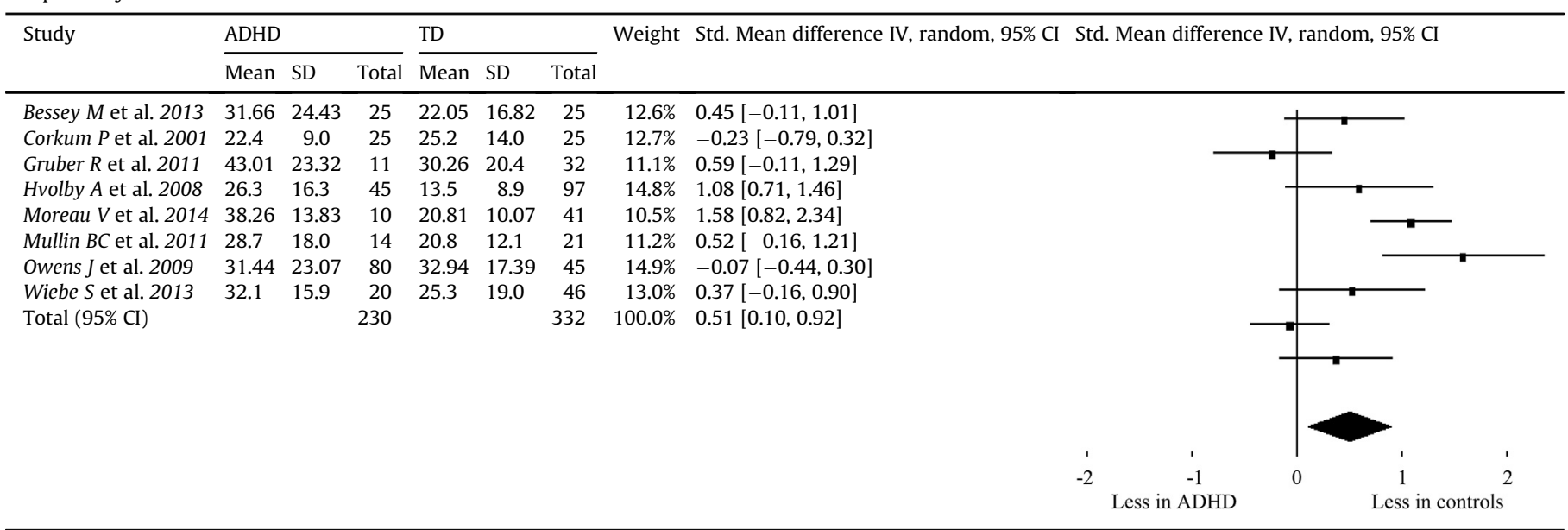

Notes: $\mathrm{ADHD}=$ attention deficit/hyperactivity disorder; $\mathrm{CI}=$ confidence interval; $\mathrm{IV}=$ inverse variance method; $\mathrm{SD}=\mathrm{standard}$ deviation; $\mathrm{TD}=$ typically developing. Heterogeneity: $\mathrm{Tau}^{2}=0.27 ; \mathrm{Chi}^{2}=33.29, \mathrm{df}=7(\mathrm{P}<0.0001) ; \mathrm{I}^{2}=79 \%$.

Test for overall effect: $\mathrm{Z}=2.44(\mathrm{P}=0.01)$.

Table 6

Sleep efficiency.

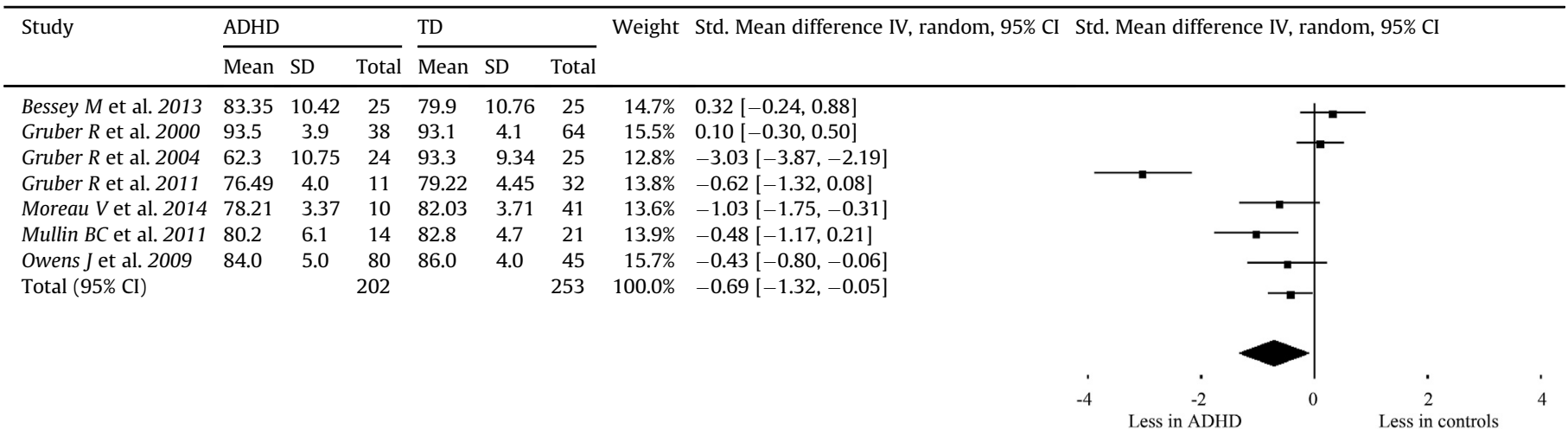

Notes: $\mathrm{ADHD}=$ attention deficit/hyperactivity disorder; $\mathrm{CI}=$ confidence interval; $\mathrm{IV}=$ inverse variance method; $\mathrm{SD}=\mathrm{standard}$ deviation; TD $=$ typically developing. Heterogeneity: $\mathrm{Tau}^{2}=0.64 ; \mathrm{Chi}^{2}=53.41, \mathrm{df}=6(\mathrm{P}<0.00001) ; \mathrm{I}^{2}=89 \%$.

Test for overall effect: $\mathrm{Z}=2.12(\mathrm{P}=0.03)$.

Table 7

Wake after sleep onset.

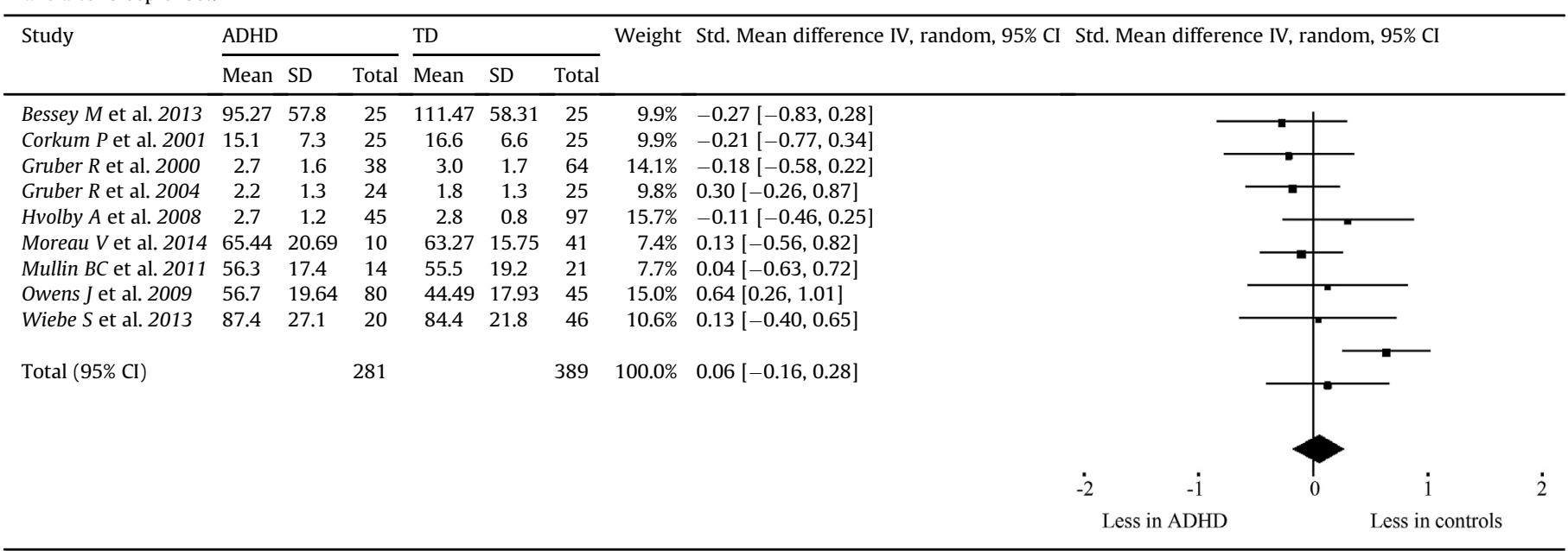

Notes: $\mathrm{ADHD}=$ attention deficit/hyperactivity disorder; $\mathrm{CI}=$ confidence interval; IV = inverse variance method; SD = standard deviation; TD = typically developing. Heterogeneity: $\mathrm{Tau}^{2}=0.05 ; \mathrm{Chi}^{2}=14.44, \mathrm{df}=8(\mathrm{P}=0.07) ; \mathrm{I}^{2}=45 \%$.

Test for overall effect: $\mathrm{Z}=0.54(\mathrm{P}=0.59)$. 
Table 8

Table of bias.

\begin{tabular}{|c|c|c|c|c|c|c|c|c|c|c|c|}
\hline & $\begin{array}{l}\text { Representative } \\
\text { spectrum? }\end{array}$ & $\begin{array}{l}\text { Acceptable reference } \\
\text { standard? }\end{array}$ & $\begin{array}{l}\text { Acceptable delay } \\
\text { between tests? }\end{array}$ & $\begin{array}{l}\text { Partial verification } \\
\text { avoided? }\end{array}$ & $\begin{array}{l}\text { Differential } \\
\text { verification } \\
\text { avoided? }\end{array}$ & $\begin{array}{l}\text { Incorporation } \\
\text { avoided? }\end{array}$ & $\begin{array}{l}\text { Reference standard } \\
\text { results blinded? }\end{array}$ & $\begin{array}{l}\text { Index test } \\
\text { results blinded? }\end{array}$ & $\begin{array}{l}\text { Relevant clinical } \\
\text { information? }\end{array}$ & $\begin{array}{l}\text { Uninterpretable } \\
\text { results reported? }\end{array}$ & $\begin{array}{l}\text { Withdrawals } \\
\text { explained? }\end{array}$ \\
\hline Miyahara M et al. 2014 & - & ? & + & - & - & + & - & - & + & + & + \\
\hline Moreau V et al. 2014 & - & + & + & + & + & + & - & - & + & + & + \\
\hline Bessey M et al. 2013 & - & ? & + & ? & + & + & - & - & + & + & + \\
\hline Wiebe S et al. 2013 & - & + & + & + & + & + & - & - & + & + & + \\
\hline Alderson $M$ et al. 2012 & - & + & + & + & + & + & - & - & + & $?$ & + \\
\hline Langevin $R$ et al. 2012 & - & + & + & + & $?$ & + & - & - & + & - & + \\
\hline Gruber R et al. 2011 & - & + & + & + & + & + & - & - & + & + & + \\
\hline Kam HJ et al. 2011 & - & + & + & + & + & + & - & - & + & + & + \\
\hline Mullin BC et al. 2011 & - & + & + & + & + & + & - & - & + & + & + \\
\hline Licht $C A$ et al. 2009 & - & + & + & + & + & + & - & - & + & + & + \\
\hline Owens J et al. 2009 & - & + & + & + & + & + & - & - & + & - & + \\
\hline Rapport MD et al. 2009 & - & + & + & + & + & + & - & - & + & + & - \\
\hline Tsujii $N$ et al. 2009 & - & ? & + & $?$ & + & + & - & - & + & + & + \\
\hline Wood AC et al. 2009 & - & ? & + & + & ? & + & - & - & + & - & + \\
\hline Halperin JM et al. 2008 & - & + & + & + & + & + & - & - & + & ? & + \\
\hline Hvolby A et al. 2008 & - & $?$ & + & + & $?$ & + & - & - & + & + & + \\
\hline Gruber $R$ et al. 2004 & - & + & + & + & + & + & - & - & + & + & + \\
\hline Salbach $\mathrm{H}$ et al. 2002 & - & + & + & + & + & + & - & - & + & - & + \\
\hline Corkum P et al. 2001 & - & ? & + & + & + & + & - & - & + & ? & + \\
\hline Dane $A V$ et al. 2000 & - & + & + & + & + & + & - & - & + & + & + \\
\hline Gruber $R$ et al. 2000 & - & - & + & - & - & + & - & - & + & - & + \\
\hline Konrad $K$ et al. 2000 & - & + & + & + & + & + & - & - & + & + & + \\
\hline Inoue $K$ et al. 1998 & - & ? & ? & ? & ? & + & - & - & + & + & + \\
\hline Halperin JM et al. 1992 & - & ? & + & + & + & + & - & - & + & ? & + \\
\hline
\end{tabular}

"+” = low risk of bias; "-“ = high risk of bias; "?” = unclear risk of bias. 
not pharmacologically treated. Moreover, actigraphic studies have shown that night-to-night variability in sleep schedule measures (e.g., sleep onset, sleep duration) is easy to differentiate between ADHD and control groups [17,46].

This meta-analysis has some limitations. Firstly, even if on the one hand statistical analyses indicate that our sample size was sufficient for the detection of significant effects for the activity mean in experimental sessions, on the other hand if we take into account only the small studies on the $24 \mathrm{~h}$ activity mean the size of our sample is underpowered. Therefore for the activity mean in the $24 \mathrm{~h}$ we suggest our results be considered with caution. Secondly, our results may be considered difficult to generalise due to the fact that the original studies used different actigraphic devices and that there is high variability among different actigraphs. However we used the SMD and the random effect model in order to be able to address this heterogeneity. Thirdly, the majority of the included studies had sleep problems or other medical conditions as exclusion criteria. Therefore it should be highlighted that our metaanalysis is valid for a subgroup of children with ADHD without medical comorbidities. Fourthly, the actigraphs are not the gold standard to evaluate sleep problems. Indeed we know that actigraphy allows the reliable, continuous recording of a child's sleep in his or her own bed, but does not allow recording of sleep architecture. However, actigraphs are handy, and in ADHD they can be easily used for the monitoring of sleep and activity in outpatient settings.

In conclusion, we think that clinicians might use actigraphy in ADHD children for the monitoring of sleep patterns and for motor activity during structured experimental sessions and for the monitoring of motor activity and sleep patterns during treatment with MPH [25], while we have only limited evidence to support the use of actigraphy in the diagnosis or as a screening tool in ADHD [37].

In this meta-analysis, we have reviewed whether actigraphy shows consistency for the monitoring of motor activity and sleep in ADHD children. We believe these findings open up new perspectives on assessment, management and therapeutic follow up in ADHD.

\section{Practice points}

In patients with ADHD actigraphy may be useful to:

1. Monitor activity mean and its clinical evolution in an outpatient setting;

2. Monitor sleep problems, mainly sleep latency and efficiency.

\section{Research agenda}

In patients with ADHD there is a need for studies which:

1. Examine if actigraphy is efficient as a monitoring tool of activity and sleep in ambulatory setting;

2. Investigate actigraphic motor activity during $24 \mathrm{~h}$;

3. Explore whether altered actigraphic parameters should be treated and if yes, how.

\section{Conflicts of interest}

The authors declare no conflict of interests.

\section{Acknowledgments}

Marco Armando was supported by a NARSAD Young Investigator Award. We would like to thank Barbaro Lo Giudice and Luke Patrick Moynihan for their invaluable support and guidance. This research project would not have been possible without Ann Sharpley (academic department of psychiatry, university of Oxford), whose work inspired this study.

\section{Appendix A. Supplementary data}

Supplementary data related to this article can be found at http:// dx.doi.org/10.1016/j.smrv.2015.04.002.

\section{References}

[1] Polanczyk GV, Willcutt EG, Salum GA, Kieling C, Rohde LA. ADHD prevalence estimates across three decades: an updated systematic review and metaregression analysis. Int J Epidemiol 2014 Apr;43(2):434-42.

[2] Spahis S, Vanasse M, Belanger SA, Ghadirian P, Grenier E, Levy E. Lipid profile, fatty acid composition and pro- and anti-oxidant status in pediatric patients with attention-deficit/hyperactivity disorder. Prostagl Leukot Essent Fat Acids 2008 Jul-Aug;79(1-2):47-53.

[3] American Psychiatric Association. 5th ed.. Arlington, VA: American Psychiatric Publishing; 2013.

[4] World Health Organisation. ICD-10 classifications of mental and behavioural disorder: clinical descriptions and diagnostic guidelines. Geneva: World Health Organisation; 1992.

[5] Goodman DW, Surman CB, Scherer PB, Salinas GD, Brown JJ. Assessment of physician practices in adult attention-deficit/hyperactivity disorder. Prim Care Companion CNS Disord 2012;14(4). http://dx.doi.org/10.4088/ PCC.11 m01312. Epub 2012 Aug 2.

[6] Kaufman J, Birmaher B, Brent D, Rao U, Flynn C, Moreci P, et al. Schedule for affective disorders and schizophrenia for school-age children-present and lifetime version (K-SADS-PL): initial reliability and validity data. J Am Acad Child Adolesc Psychiatry 1997 Jul;36(7):980-8.

[7] Conners CK. Conners. 3rd ed. Toronto: Multi-Health Systems Inc; 2008.

[8] Wechsler D. Wechsler intelligence scale for children. 4th ed. San Antonio, TX: Harcourt Assessment, Inc.; 2003.

[9] Subcommittee on Attention-Deficit/Hyperactivity Disorder, Steering Committee on Quality Improvement and Management, Wolraich M, Brown L, Brown RT, DuPaul G, Earls M, Feldman HM, et al. ADHD: clinical practice guideline for the diagnosis, evaluation, and treatment of attention-deficit/ hyperactivity disorder in children and adolescents. Pediatrics 2011 Nov;128(5):1007-22

*[10] van der Heijden KB, Smits MG, Gunning WB. Sleep hygiene and actigraphically evaluated sleep characteristics in children with ADHD and chronic sleep onset insomnia. J Sleep Res 2006 Mar;15(1):55-62.

[11] Charach A, Carson P, Fox S, Ali MU, Beckett J, Lim CG. Interventions for preschool children at high risk for ADHD: a comparative effectiveness review. Pediatrics 2013 May:131(5):e1584-604.

[12] Brown RT, Amler RW, Freeman WS, Perrin JM, Stein MT, Feldman HM, et al. Treatment of attention-deficit/hyperactivity disorder: overview of the evidence. Pediatrics 2005 Jun;115(6):e749-57.

[13] Van der Oord S, Prins PJ, Oosterlaan J, Emmelkamp PM. Efficacy of methylphenidate, psychosocial treatments and their combination in school-aged children with ADHD: a meta-analysis. Clin Psychol Rev 2008 Jun;28(5): $783-800$.

[14] Swanson JM, Sergeant JA, Taylor E, Sonuga-Barke EJS, Jensen PS, Cantwell DP. Attention-deficit hyperactivity disorder and hyperkinetic disorder. Lancet 1998:351(9100):429-33.

[15] Biederman J. Attention-deficit/hyperactivity disorder: a selective overview. Biol Psychiatry 2005;57(1):1215-20.

*[16] Owens J, Sangal RB, Sutton VK, Bakken R, Allen AJ, Kelsey D. Subjective and objective measures of sleep in children with attention-deficit/hyperactivity disorder. Sleep Med 2009 Apr;10(4):446-56.

*[17] Gruber R, Sadeh A, Raviv A. Instability of sleep patterns in children with attention-deficit/hyperactivity disorder. J Am Acad Child Adolesc Psychiatry 2000 Apr;39(4):495-501.

[18] Fallone G, Owens JA, Deane J. Sleepiness in children and adolescents: clinical implications. Sleep Med Rev 2002 Aug;6(4):287-306.

\footnotetext{
* The most important references are denoted by an asterisk.
} 
*[19] Corkum P, Tannock R, Moldofsky H, Hogg-Johnson S, Humphries T. Actigraphy and parental ratings of sleep in children with attention-deficit/ hyperactivity disorder (ADHD). Sleep 2001 May 1;24(3):303-12.

[20] Yoon SY, Jain U, Shapiro C. Sleep in attention-deficit/hyperactivity disorder in children and adults: past, present, and future. Sleep Med Rev 2012 Aug; $16(4): 371-88$.

[21] Konofal E, Lecendreux M, Cortese S. Sleep and ADHD. Sleep Med 2010 Aug; 11(7):652-8.

*[22] Martin JL, Hakim AD. Wrist actigraphy. Chest 2011 Jun;139(6):1514-27.

*[23] Morgenthaler T, Alessi C, Friedman L, Owens J, Kapur V, Boehlecke B, et al. Practice parameters for the use of actigraphy in the assessment of sleep and sleep disorders: an update for 2007. Sleep 2007 Apr;30(4):519-29.

*[24] Sadeh A. The role and validity of actigraphy in sleep medicine: an update. Sleep Med Rev 2011 Aug;15(4):259-67.

*[25] De Crescenzo F, Armando M, Mazzone L, Ciliberto M, Sciannamea M, Figueroa $C$, et al. The use of actigraphy in the monitoring of methylphenidate versus placebo in ADHD: a meta-analysis. Atten Defic Hyperact Disord 2014 Mar;6(1):49-58.

[26] Whiting P, Rutjes AW, Reitsma JB, Bossuyt PM, Kleijnen J. The development of QUADAS: a tool for the quality assessment of studies of diagnostic accuracy included in systematic reviews. BMC Med Res Methodol 2003 Nov 10;3:25.

[27] Higgins JP, Green S. Cochrane handbook for systematic reviews of interventions version 5.1.0. Available from: www.cochrane-handbook.org.. The cochrane collaboration; . .:

[28] Higgins JP, Thompson SG, Deeks JJ, Altman DG. Measuring inconsistency in meta-analyses. BMJ 2003 Sep 6;327(7414):557-60.

*[29] Miller RG. The Jackknife-a review. Biometrika 1974;61(1):1-15.

[30] Miyahara M, Healey DM, Halperin JM. One-week temporal stability of hyperactivity in preschoolers with ADHD during psychometric assessment. Psychiatry Clin Neurosci 2014 Feb;68(2):120-6.

[31] Moreau V, Rouleau N, Morin CM. Sleep of children with attention deficit hyperactivity disorder: actigraphic and parental reports. Behav Sleep Med 2014;12(1):69-83.

[32] Bessey M, Richards J, Corkum P. Sleep lab adaptation in children with attention-deficit/hyperactivity disorder and typically developing children. Sleep Disord 2013;2013:698957.

[33] Wiebe S, Carrier J, Frenette S, Gruber R. Sleep and sleepiness in children with attention deficit/hyperactivity disorder and controls. J Sleep Res 2013 Feb;22(1):41-9.

[34] Alderson RM, Rapport MD, Kasper LJ, Sarver DE, Kofler MJ. Hyperactivity in boys with attention deficit/hyperactivity disorder (ADHD): the association between deficient behavioral inhibition, attentional processes, and objectively measured activity. Child Neuropsychol 2012;18(5):487-505.

[35] Langevin R, Ramde J. Attention deficit hyperactivity disorder (ADHD) in children, seasonal photoperiods, nocturnal movements and diurnal agitation. J Can Acad Child Adolesc Psychiatry 2012 Feb;21(1):53-8.

[36] Gruber R, Wiebe S, Montecalvo L, Brunetti B, Amsel R, Carrier J. Impact of sleep restriction on neurobehavioral functioning of children with attention deficit hyperactivity disorder. Sleep 2011 Mar 1;34(3):315-23.

[37] Kam HJ, Shin YM, Cho SM, Kim SY, Kim KW, Park RW. Development of a decision support model for screening attention-deficit hyperactivity disorder with actigraph-based measurements of classroom activity. Appl Clin Inf 2010 Nov 10;1(4):377-93.

[38] Mullin BC, Harvey AG, Hinshaw SP. A preliminary study of sleep in adolescents with bipolar disorder, ADHD, and non-patient controls. Bipolar Disord 2011 Jun;13(4):425-32.

[39] Licht CA, Tryon WW. Are children diagnosed with the combined form of ADHD pervasively hyperactive? Behav Modif 2009 Sep;33(5):655-81.
[40] Owens JA. The ADHD and sleep conundrum: a review. J Dev Behav Pediatr 2005 Aug;26(4):312-22.

[41] Rapport MD, Bolden J, Kofler MJ, Sarver DE, Raiker JS, Alderson RM. Hyperactivity in boys with attention-deficit/hyperactivity disorder (ADHD): a ubiquitous core symptom or manifestation of working memory deficits? J Abnorm Child Psychol 2009 May;37(4):521-34.

[42] Tsujii N, Okada A, Kaku R, Kuriki N, Hanada K, Shirakawa O. Differentiation between attention-deficit/hyperactivity disorder and pervasive developmental disorders with hyperactivity on objective activity levels using actigraphs. Psychiatry Clin Neurosci 2009 Jun;63(3):336-43.

[43] Wood AC, Asherson P, Rijsdijk F, Kuntsi J. Is overactivity a core feature in ADHD? Familial and receiver operating characteristic curve analysis of mechanically assessed activity level. J Am Acad Child Adolesc Psychiatry 2009 Oct;48(10):1023-30.

[44] Halperin JM, Trampush JW, Miller CJ, Marks DJ, Newcorn JH. Neuropsychological outcome in adolescents/young adults with childhood ADHD: profiles of persisters, remitters and controls. J Child Psychol Psychiatry 2008 Sep;49(9):958-66.

[45] Hvolby A, Jorgensen J, Bilenberg N. Actigraphic and parental reports of sleep difficulties in children with attention-deficit/hyperactivity disorder. Arch Pediatr Adolesc Med 2008 Apr;162(4):323-9.

[46] Gruber R, Sadeh A. Sleep and neurobehavioral functioning in boys with attention-deficit/hyperactivity disorder and no reported breathing problems. Sleep 2004 Mar 15;27(2):267-73.

[47] Salbach H, Huss M, Lehmkuhl U. Impulsiveness in children with hyperkinetic syndrome. Prax Kinderpsychol Kinderpsychiatr 2002 Jul-Aug;51(6):466-75.

[48] Dane AV, Schachar RJ, Tannock R. Does actigraphy differentiate ADHD subtypes in a clinical research setting? J Am Acad Child Adolesc Psychiatry 2000 Jun;39(6):752-60.

[49] Konrad K, Gauggel S, Manz A, Scholl M. Inhibitory control in children with traumatic brain injury (TBI) and children with attention deficit/hyperactivity disorder (ADHD). Brain Inj 2000 Oct;14(10):859-75.

[50] Inoue K, Nadaoka T, Oiji A, Morioka Y, Totsuka S, Kanbayashi Y, et al. Clinical evaluation of attention-deficit hyperactivity disorder by objective quantitative measures. Child Psychiatry Hum Dev 1998;28(3):179-88. Spring.

[51] Halperin JM, Matier K, Bedi G, Sharma V, Newcorn JH. Specificity of inattention, impulsivity, and hyperactivity to the diagnosis of attention-deficit hyperactivity disorder. J Am Acad Child Adolesc Psychiatry 1992 Mar;31(2): 190-6.

[52] Biederman J, Faraone SV. The Massachusetts general hospital studies of gender influences on attention-deficit/hyperactivity disorder in youth and relatives. Psychiatr Clin North Am 2004 Jun;27(2):225-32.

[53] Wolraich ML, McKeown RE, Visser SN, Bard D, Cuffe S, Neas B, et al. The prevalence of ADHD: its diagnosis and treatment in four school districts across two states. J Atten Disord 2014 Oct;18(7):563-75.

[54] Moreau V, Rouleau N, Morin CM. Sleep, attention, and executive functioning in children with attention-deficit/hyperactivity disorder. Arch Clin Neuropsychol 2013 Nov;28(7):692-9.

[55] Hatzinger M, Brand S, Perren S, Von Wyl A, Stadelmann S, von Klitzing K, et al. In pre-school children, sleep objectively assessed via actigraphy remains stable over 12 months and is related to psychological functioning, but not to cortisol secretion. J Psychiatr Res 2014 Aug;55:22-8.

*[56] Cortese S, Faraone SV, Konofal E, Lecendreux M. Sleep in children with attention-deficit/hyperactivity disorder: meta-analysis of subjective and objective studies. J Am Acad Child Adolesc Psychiatry 2009 Sep;48(9): 894-908. 